\title{
ANALYSIS OF THE EFFECT OF ISLAMIC LEADERSHIP ON TEACHER PERFORMANCE AT THE AL-MARWA COLLEGE FOUNDATION IN THE INDUSTRIAL REVOLUTION ERA 4.0
}

\author{
Munawaroh $^{1}$, Horia Siregar ${ }^{2}$, Sri Fitria Jayusman ${ }^{3}$, Melisa Zuriani Hsb ${ }^{4}$ \\ ${ }^{1.2 .3 .4}$ Faculty of Economics, Universitas Muslim Nusantara Al Washliyah \\ E-mail: munawaroh@umnaw.ac.id
}

\begin{abstract}
Entering the era of the industrial revolution 4.0 has opportunities and challenges for schools around the world. The Al Marwa Foundation school is no exception. The Al Marwa college foundation must be able to survive in the midst of environmental changes and increasingly extraordinary competition. To be able to survive and achieve the vision, mission and goals of the foundation. Human resources have a very important role and function for the sustainability of education in the world. The purpose of this study was to determine the effect of Islamic leadership style on teacher performance at the Al Marwa Islamic boarding school foundation. This study uses a quantitative descriptive approach. The total population in this study were 30 respondents using a saturated sample. Data was collected by providing a list of statements to respondents, namely RA, MIS, and MDA teachers at the Al Marwa Islamic Boarding School Foundation. The results showed that the value of $t$ arithmetic (3.776) $>t$ table (1.701) this indicates that there is a positive effect. As for the significance value $(0.001<0.05)$, the Islamic Leadership Style variable has a positive and significant impact on teacher performance at the Al Marwa College Foundation.
\end{abstract}

Keywords: Industrial Revolution 4.0, Islamic Leadership Style, Teacher Performance, Al Marwa . Foundation

\section{INTRODUCTION}

Today the world has entered the era of the industrial revolution generation 4.0 which is marked by increased connectivity, interaction and development of digital systems, artificial intelligence, and virtual. With the increasingly convergent boundaries between humans, machines and other resources, information and communication technology certainly has an impact on various sectors of life. One of them is the impact on the education system in Indonesia.

Changes in this era cannot be avoided by anyone so that adequate preparation of human resources (HR) is needed in order to be able to adapt and be able to compete on a global scale. Improving the quality of human resources through education channels ranging from primary and secondary education to tertiary institutions is the key to being able to keep up with the development of the Industrial Revolution 4.0.

The success of a country in facing the industrial revolution 4.0 is also determined by the quality of educators such as teachers. Teachers are required to master the skills, the ability to adapt to new technologies and global challenges. In this situation, every educational institution must prepare a new orientation and literacy in the field of education. For this reason, the role of the principal as one of the drivers, determining school policies, determining how school goals and educational goals in general, can be realized, which in the end the quality of education will be realized (Sriwahyuni and Kristiawan, 2019; Aprilana et al, 2017).

So that the realization of quality education is not only determined by the principal, but the role of teachers also greatly influences success in educating the nation's children. Teacher performance can be seen from the sense of responsibility in carrying out the mandate of the 
profession carried out and the sense of moral responsibility that is on his shoulders. All of that will be seen in obedience and loyalty in carrying out teacher duties in the classroom and outside the classroom (Sri Setiyati, 2014: 201).

Uhar Suhar Saputra in Engkay Karweti said that teacher performance is basically a performance carried out by teachers in carrying out their duties as educators (Uhar Suharsaputra, 2014: 77). As it is known that teacher performance is the result of the teacher's work shown in carrying out tasks, roles and responsibilities based on skills and experience and sincerity. However, in this case the teacher's performance is related to his duties in teaching.

In the current industrial era 4.0, it provides new opportunities and challenges for school principals and teachers so that they can survive in the competition in the world of education. Teacher performance is required to develop and advance following technological sophistication for the survival of the world of education.

One of the factors that can affect teacher performance is Islamic leadership played by the principal. The Islamic leadership style applied by the principal is very important and is expected to be able to carry out effective leadership in the sense of being able to develop and build leadership oriented to school management in the industrial 4.0 era as it is today.

Leadership in Islam is an activity of guiding, guiding, guiding and showing the way that is blessed by Allah SWT. So the main orientation in Islamic leadership is the pleasure of Allah. Leadership according to Islam is deliberation, fairness and freedom of thought. Through deliberation the decision-making process can be achieved. In deliberation all parties can play a role in deciding, not only the leader in power here. A leader must also act fairly and impartially, whoever is right must be defended and the wrong must be punished.

In its history, globalization has shown that every changing era has its own core (driver) (Prasetyo, 2018). In the industrial era 4.0 which is very fast and sophisticated, an Islamic leadership style is needed who can and is able to follow technological developments in carrying out their leadership so that the goals expected by schools can be achieved, especially in improving the performance of teachers in schools, especially the performance of teachers at the Al Marwa College Foundation. Islamic Boarding School.

Based on the background of the problem above, the author is interested in researching "Analysis of the Effect of Islamic Leadership Style on Teacher Performance at the Al Marwa College Foundation in the Era of the Industrial Revolution 4.0".

\section{IMPLEMENTATION METHOD}

Data analysis in this research is descriptive associative using quantitative approach method. The data collection technique carried out in this study was by providing a list of statements to respondents by preparing a set of questions that were systematically arranged and standards given to respondents to be answered about the variables studied, then the answers were scored using a Likert Scale. . The Likert scale has an interval of 1-5. For answers that support the question or questions are given the highest score and for answers that do not support the question or questions are given the lowest score. 


\section{RESULT AND DISCUSSION}

Table 1 . Normality Test

\begin{tabular}{lllllll}
\multicolumn{4}{c}{ Kolmogorov-Smirnova } & \multicolumn{3}{c}{ Shapiro-Wilk } \\
\multicolumn{3}{c}{ Statistics df } & Sig. & Statistics & df & Sig. \\
\hline $\begin{array}{l}\text { Perfor } \\
\text { mance }\end{array}$ & .155 & 30 & .063 & .962 & 30 & .350 \\
\hline
\end{tabular}

Table 1 shows that the Sig value is 0.063 with a statistical test of 0.155 on the basis that if the probability ( $\mathrm{sig}$ ) $>0.05$ means the data is normally distributed, and from the SPSS test results obtained a significance value of 0.063 then the value is $0.063>0.05$ which means that the data in this study were normally distributed.

Table 2. Simple Linear Regression Test

\begin{tabular}{|c|c|c|c|c|c|c|}
\hline \multirow{2}{*}{\multicolumn{2}{|c|}{ Model }} & \multicolumn{2}{|c|}{$\begin{array}{c}\text { Unstandardized } \\
\text { Coefficients }\end{array}$} & \multirow{2}{*}{$\begin{array}{l}\text { Standardized } \\
\text { Coefficients } \\
\text { Beta }\end{array}$} & \multirow[b]{2}{*}{$\mathrm{T}$} & \multirow[b]{2}{*}{ Sig. } \\
\hline & & B & Std. Error & & & \\
\hline 1 & (Constant) & 22,371 & 5,391 & & 4.149 & .000 \\
\hline & Islamic Leadership & .477 & .126 & .581 & 3.776 & .001 \\
\hline
\end{tabular}

Table 2 shows that from the simple linear regression equation above it can be predicted how much influence the Islamic Leadership Style (X) variable has on Teacher Performance (Y), this shows that the constant (a) is 22,371, meaning that if the Islamic Leadership Style (X) is 0, then the volume of Teacher Performance (Y) the value is 22,371 . While the regression coefficient (b) is 0.477 , meaning that if the teacher's performance increases by 1 , then the teacher's performance will increase by 0.477 .

Table 3. T . test

\begin{tabular}{|c|c|c|c|c|c|c|}
\hline \multirow{2}{*}{\multicolumn{2}{|c|}{ Model }} & \multicolumn{2}{|c|}{$\begin{array}{l}\text { Unstandardized } \\
\text { Coefficients }\end{array}$} & \multicolumn{2}{|c|}{$\begin{array}{l}\text { Standardized } \\
\text { Coefficients }\end{array}$} & \multirow[b]{2}{*}{ Sig. } \\
\hline & & $\mathrm{B}$ & Std. Error & Beta & $\mathrm{t}$ & \\
\hline$\overline{1}$ & (Constant) & 22,371 & 5,391 & & 4.149 & .000 \\
\hline & Islamic Leadership & .477 & .126 & .581 & 3.776 & .001 \\
\hline
\end{tabular}

Table 3 shows that the value of $t$ arithmetic (3.776) $>t$ table (1.701) this indicates that there is a positive effect. As for the significance value $(0.001<0.05)$. From the output above, it can be concluded that Ho is rejected and Ha is accepted. This shows that the Islamic leadership style variable $(\mathrm{X})$ has a positive and significant effect on teacher performance $(\mathrm{Y})$ at the Al Marwa Islamic Boarding School Foundation. 
ANALYSIS OF THE EFFECT OF ISLAMIC LEADERSHIP ON TEACHER PERFORMANCE AT THE AL-MARWA COLLEGE FOUNDATION IN THE INDUSTRIAL REVOLUTION ERA 4.0

DOI: https://doi.org/10.54443/ijebas.v2i1.152

Table 4. Coefficient of Determination Test

\begin{tabular}{|c|c|c|c|c|}
\hline \multicolumn{5}{|c|}{ Model Summaryb } \\
\hline Mo & $\mathrm{R}$ & R Square & $\begin{array}{c}\text { Adjusted R } \\
\text { Square }\end{array}$ & $\begin{array}{l}\text { Std. Error of the } \\
\text { Estimate }\end{array}$ \\
\hline$\overline{1}$ & $.581 \mathrm{a}$ & .337 & .314 & 2,346 \\
\hline
\end{tabular}

Table 4 shows that the value of $\mathrm{R}$ Square is 0.337 . This means that the influence of Islamic Leadership Style on Teacher Performance is $33.7 \%$, which means that it has an effect in accordance with the correlation interpretation. While $66.3 \%$ is influenced by other variables not examined in this study.

\section{DISCUSSION}

The results of calculations to find the effect of Islamic Leadership Style (X) on Teacher Performance $(\mathrm{Y})$ using a significant test with a significant level of 0.05 , it is known that the significant value of Islamic Leadership Style (X) on Teacher Performance (Y) is $0.001<0.05$, then there is a significant effect of Islamic Leadership Style (X) on Teacher Performance (Y) at Al Marwa Islamic Boarding School Foundation. The results showed that Islamic Leadership Style had a positive and significant effect on teacher performance.

The Islamic Leadership Policy that is implemented and the role model of a leader will make teachers put their trust in the principal/foundation whose impact makes it easier for teachers to work together and be committed to their work. Teacher orientation also affects teacher performance indicators, namely performance in teaching students. This is because clear directions related to the teacher's duties both in instructional and disciplinary rules make the teacher's performance in carrying out tasks more reliable, effective and efficient.

\section{CONCLUSION}

Using SPSS version 23 in testing Islamic leadership style on teacher performance, the results were positive and significant. These results are seen from the data processing of the t-test results, namely, the value of $t$ count $(3.776)>t$ table $(1.701)$. As for the significance value $(0.001<0.05)$, the Islamic Leadership Style variable has a positive and significant impact on teacher performance at the Al Marwa College Foundation. The Islamic leadership style variable has been proven to affect teacher performance in teaching in schools, this can be seen from the results of testing the coefficient of determination (R2) of $33.7 \%$.

An honest and trustworthy Islamic leadership style must be a concern for Foundation leaders or school principals. So that teachers will feel comfortable in carrying out the learning process at school, carrying out the rules that apply at school, and being trustworthy in delivering lessons to students at school. So that teachers can improve their performance in carrying out their responsibilities at the Al Marwa Foundation in accordance with Islamic law.

\section{REFERENCES}

Burhanuddin. (1994). Analisiis Administrasi Manajemen dan Kepemimpinan Pendididkan . Jakarta: Bumi Aksara.

Fadli, F., Tambarta Kembaren, E. ., \& Sinta, I. . (2021). MAPPING VALUE ADDED ARABICA COFFEE PROCESSED PRODUCTS IN ACEH TENGAH. International Journal of Economic, Business, Accounting, Agriculture Management and Sharia Administration (IJEBAS), 1(2), 
105-112. https://doi.org/10.54443/ijebas.v1i1.28

Fanni Adhistya Italiani. (2013). Pengaruh Gaya Kepemimpinan Transformasional Dan Transaksional Terhadap Kinerja Pegawai Departemen Sdm Pt. Semen Gresik (Persero) Tbk. Jurnal Bisnis Dan Manajemen Volume 6 No. 1 Agustus, 6(1), 11-18.

Fitriyah, I., \& Santosa, A. B. (2020). Kepemimpinan Kepala Sekolah Dalam Menghadapi Era

Revolusi Industri 4.0 Untuk Meningkatkan Mutu Sekolah. JMKSP (Jurnal Manajemen,

$\begin{array}{lllll}\text { Kepemimpinan, } & \text { Dan } & \text { Supervisi }\end{array}$ https://doi.org/10.31851/jmksp.v5i1.3538.

Gaspar, M., Julião, J., \& Cruz, M. (2019). Organizational strategies induced by the fourth industrial revolution: Workforce awareness and realignment. Lecture Notes in Electrical Engineering, 330-336. https://doi.org/10.1007/978-3-319-91334-6_45

Hamzah B. Uno \& Nina Lamatenggo. (2012). Teori Kinerja dan Pengukurannya. Jakarta: Raja Grafindo Persada.

Husain, B. A. (2019). Pengaruh Gaya Kepemimpinan Kepala Sekolah Terhadap Kinerja Guru Pada SMA Adzkia Islamic School. JENIUS (Jurnal Ilmiah Manajemen Sumber Daya Manusia), 2(3), 334. https://doi.org/10.32493/jjsdm.v2i3.3013

Kristiawan, M., Yuniarsih, Y., \& Fitria, H. (2019). Supervisi Pendidikan. Bandung: Alfabeta.

Mangkunegara, Anwar Prabu, Manajemen Sumber Daya Manusia Perusahaan, Bandung: PT Remaja Rosdakarya, 2001.

Mangkunegara. (2001). Manajemen Sumber Daya Manusia Perusahaan. Bandung: REmaja Rosdakarya.

Mukhlasin, A., Era, D. I., \& Industri, R. (2019). 130-236-1-Sm. 3(1), 674-692.

Nasution, L., \& Ichsan, R. N. (2020). Gaya Kepemimpinan Kepala Sekolah Terhadap Kinerja Guru. Jurnal Penelitian Pendidikan Sosial Humaniora, 5(2), 78-86. https://jurnallp2m.umnaw.ac.id/index.php/JP2SH/article/view/473

Nurkolis. (2006). Manajemen Berbasis Sekolah. Jakarta: Grasindo.

Paizal, I., Siraj, A., \& Mania, S. (2019). Hubungan Gaya Kepemimpinan Kepala Madrasah dengan Kinerja Guru di Madrasah Aliyah Pondok Pesantren Al-Ikhlas Ujung Bone. Jurnal Pendidikan Agama Islam Al-Thariqah, 4(1), 21-37. https://doi.org/10.25299/althariqah.2019.vol4(1).3003

Purwanto, A., Asbari, M., \& Hari Hadi, A. (2020). Pengaruh Gaya Kepemimpinan Tansformational, Authentic, Authoritarian, Transactional terhadap Kinerja Guru Pesantren di Tangerang. Dirasah: Jurnal Studi Ilmu Dan Manajemen Pendidikan Islam, 3(1), 85-110. https://doi.org/10.29062/dirasah.v3i1.84

Rahman, A., \& Nuryana, Z. (2019). Pendidikan Islam di Era Revolusi Industri 4.0. 34-0. https://doi.org/10.31219/osf.io/8xwp6

Rina, H., Saputra, R. R., Darmanto, R., Tinggi, S., Tarbiyah, I., Al, S., \& Barat, M. (2020). Pengaruh Motivasi dan Gaya Kepemimpinan Kepala Sekolah terhadap Kinerja Guru Effect of Motivation and Principal Leadership Styles on Teacher Performance I . PENDAHULUAN Pendidikan yang bermutu dan berkualitas tentunya akan menghasilkan sumber daya manusia. Jurnal Manajemen Pendidikan Islam (JMPI), 05(1), 31-44.

Sriwahyuni, E., \& Kristiawan, M. (2019). Strategi Kepala Sekolah Dalam Mengimplementasikan Standar Nasional Pendidikan (SNP) Pada SMK Negeri 2 Bukittinggi. JMKSP (Jurnal Manajemen, Kepemimpinan, dan Supervisi Pendidikan), 4(1).

Thoha, M. (2006). Kepemimpinan Dalam Manajemen. Jakarta: Grafindo Persada. 
ANALYSIS OF THE EFFECT OF ISLAMIC LEADERSHIP ON TEACHER PERFORMANCE AT THE AL-MARWA COLLEGE FOUNDATION IN THE INDUSTRIAL REVOLUTION ERA 4.0

DOI: https://doi.org/10.54443/ijebas.v2i1.152

Wirawan. (2009). Kinerja Sumber Daya Manusia. Teori Aplikasi dan penelitian.

Yusro, M. (2018). Strategi Peningkatan Mutu Akreditasi Sekolah Menengah Kejuruan (SMK) Memasuki Era Revolusi. 3(peringkat 11), 9-13. 